Article

\title{
Actinomycete Strains Isolated from Saline Soils: Plant-Growth-Promoting Traits and Inoculation Effects on Solanum lycopersicum
}

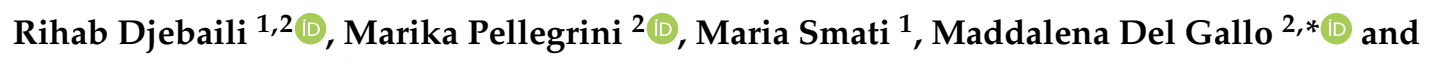 \\ Mahmoud Kitouni ${ }^{1}$ (D) \\ 1 Laboratory of Microbiological Engineering and Applications, University of Brothers Mentouri, \\ Constantine 1, Chaâbat Erssas Campus, Ain El Bey Road, Constantine 25000, Algeria; \\ djebaili.rihab@umc.edu.dz (R.D.); mariasmati87@gmail.com (M.S.); mahmoudkitouni@yahoo.fr (M.K.) \\ 2 Department of Life, Health and Environmental Sciences, University of L'Aquila, Coppito, \\ 67010 L'Aquila, Italy; marika.pellegrini@guest.univaq.it \\ * Correspondence: maddalena.delgallo@univaq.it; Tel.: +39-0862-433258
}

Received: 27 April 2020; Accepted: 2 June 2020; Published: 5 June 2020

check for updates

\begin{abstract}
Excessive use of chemical products in agriculture is causing significant environmental pollution and the loss of lands and fertility of agricultural soils. Plant-growth-promoting bacteria are a valid alternative strategy for sustainable agriculture. The aim of this study was to select actinomycete strains based on their plant-growth-promoting traits and to investigate their root association abilities and biostimulant effects on Solanum lycopersicum. The strains were investigated for their phosphate solubilization ability, production of indole-3-acetic acid, hydrocyanic acid, and ammonia, and several enzymatic activities. Bacteria-plant-root associations were studied by scanning electron microscopy. A greenhouse experiment was carried out to assess inoculation effects. Of sixty isolates, fourteen strains showed significant plant-growth-promoting traits. All fourteen strains solubilized phosphate, produced ammonia, and showed several enzymatic activities at different rates. The production of indole-3-acetic acid was shown by nine strains, while hydrocyanic acid production was observed in eleven of them. Scanning electron microscopy revealed that strains have good in vitro plant root association and colonization abilities. In planta inoculation by actinomycete strains positively influenced plant growth parameters. The best results were shown by seven actinomycete strains, suggesting their possible utilization as biofertilizer agents for sustainable agriculture.
\end{abstract}

Keywords: PGPB; actinomycetes; phosphate solubilization; indole-3-acetic acid; hydrocyanic acid; tomato; biofertilizer

\section{Introduction}

With population increase and territory occupation by humans, improvement of crop productivity has become one of the major concerns in satisfying food needs worldwide [1]. Application of chemical fertilizers is the simplest way to qualitatively and quantitatively increase crop yields. For this reason, demand for fertilizers and pesticides has grown dramatically and is expected to continue growing more and more in the next years [2]. However, an indiscriminate use of chemicals in agriculture entails quite a few environmental problems-i.e., water, air, and soil contamination. It causes toxicity in non-target organisms, as well as in humans due to the occurrence in food as residues. Furthermore, a decrease of chemicals' effectiveness was observed due to an ensuing resistance by pests [3].

Biofertilization can replace the use of agrochemicals in agriculture. Biofertilization is considered as a key element towards the development of a sustainable agriculture. Plant-growth-promoting bacteria (PGPB) have a positive effect on crop productivity by preserving soil fertility [4], whilst safeguarding 
human health and keeping the diversity of living organisms [5,6]. These microorganisms promote plant growth and development through several mechanisms (direct and indirect). These include: Organic matter decomposition and nutritional element recycling [7], atmospheric nitrogen fixation, mineral solubilization (e.g., phosphorus), and phytohormone production (e.g., auxins, cytokinins, gibberellins) [8]. These microorganisms help the plant respond to several biotic and abiotic stresses through different mechanisms, such as 1-aminocyclopropane-1-carboxylate (ACC) deaminase activity, release of enzymes, and production of siderophores [9-11]. Currently, soil salinity is one of the major concerns in agriculture [12] that limits water absorption and induces accumulation of toxic ions in the different plants' organs [13]. The application of halotolerant plant-growth-promoting (PGP) strains can be a valid tool to reduce the harmful effects of saline stress and to improve crop productivity [14].

The PGPB group includes a wide range of species $[7,9,11,15]$. Within this group, a significant role is played by actinomycetes. These ubiquitous Gram-positive bacteria-aerobic, but with some anaerobic strains-are widely distributed in the soil, in which they occupy $10 \%$ to $50 \%$ of the microbial community $[16,17]$. They exhibit a remarkable pleomorphism, displaying the greatest differentiation among bacteria by forming complicated structures, such as spores, spore chains, sporangia, and sporangiospores. While individual bacteria are rod-shaped or coccoid-the latter form is generally called a spore or arthrospore, even if it is not a real spore because it is a vital form that divides, keeping this form-actinomycete colonies form fungus-like branched networks of hyphae. This morphology allows them to create a strong bond with the soil particles within the rhizosphere, allowing strong associations with plants [18].

Several authors reported positive influence on plants treated by actinomycete strains, either singularly or in consortium. In particular, actinomycetes improve plant growth through direct mechanisms, such as phytohormone synthesis (i.e., indole-3-acetic acid (IAA) $[19,20]$, ethylene, gibberellic acid, and cytokines [21]), supply of nutrients to plants through the solubilization of essential elements, such as phosphate [22], production of siderophores, and fixation of atmospheric nitrogen [18]. Moreover, many actinomycetes can control phytopathogens through antifungal, insecticide, and antibacterial activities [18] and production of hydrolytic enzymes and hydrogen cyanide [23,24].

The aim of the present work was to select actinomycete strains with plant-growth-promoting traits, to assess their abilities and patterns of root association and colonization, and to determine their effects on the growth of Solanum lycopersicum. Actinomycete isolates were firstly screened through several in vitro plant-growth-promoting (PGP) traits (i.e., phosphate solubilization ability, production of indole-3-acetic acid, hydrocyanic acid, and ammonia, and several enzymatic activities). Strains with interesting traits were investigated for their root association and colonization abilities and biostimulant effects on S. lycopersicum. Root association and colonization abilities were studied in in vitro seedlings using scanning electron microscopy (SEM). Biostimulant properties were assessed through a greenhouse experiment.

\section{Materials and Methods}

\subsection{Actinomycete Strains and Culture Conditions}

Sixty actinomycete strains of the genus Streptomyces sp. and Nocardiopsis sp., isolated from two different sites in the Northeast region of Algeria-Ezzemoul sebkha ( $35^{\circ} 53^{\prime} 14^{\prime \prime} \mathrm{N} ; 06^{\circ} 30^{\prime} 20^{\prime \prime} \mathrm{E}$ ) and Djendli sebkha $\left(35^{\circ} 43^{\prime} 15^{\prime \prime} \mathrm{N} ; 06^{\circ} 32^{\prime} 23^{\prime \prime}\right.$ E) —as previously reported in Smati and Kitouni [25], were investigated for their PGP traits.

A primary screening to select PGPB strains was carried out: Abilities to solubilize phosphate and to produce indole 3-acetic acid (IAA) and hydrocyanic acid (HCN).

Spore production by each strain was determined by cultivation on ISP2 agar medium (the International Streptomyces Project No. 2) at $30^{\circ} \mathrm{C}$ for 7 days. Spore suspensions were prepared by sterile distilled water addition into the plates. The concentration of the spores was adjusted 
spectrophotometrically to a final density of $10^{6}$ spores $\mathrm{mL}^{-1}$. Spore suspensions were utilized differently depending on the test carried out (descriptions reported in each paragraph).

\subsection{Plant-Growth-Promoting Traits}

\subsubsection{Phosphate Solubilization}

To assess the strains' ability to dissolve inorganic phosphate, $5 \mathrm{~mm}$ agar plugs of each actinomycete strains (collected from cultivated plates of ISP2 media kept at $30^{\circ} \mathrm{C}$ for 7 days) were placed in plates with three different media containing $\mathrm{Ca}_{3}\left(\mathrm{PO}_{4}\right)_{2}$ as the only source of phosphate: NBRIP (National Botanical Research Institute's Growth Medium) [26], PVK (Pikovskaya) [27], and LB (Luria Bertani) modified by glucose addition. The solubilization ability was estimated by measuring the transparent area formed around the colony after 7 days of incubation at $30^{\circ} \mathrm{C}$. The diameter of the solubilization halo for each isolate was determined by subtracting colony diameter from the total one (diameter of the halo - diameter of the colony) [28].

Quantification of solubilized phosphate was carried out in liquid PVK. Spore suspension of each strain $(100 \mu \mathrm{L})$ was inoculated in $10 \mathrm{~mL}$ of liquid PVK medium and incubated at $30^{\circ} \mathrm{C}$ for 7 days in a rotary shaker at $150 \mathrm{rpm}$. After incubation, the cultures were centrifuged at $3000 \mathrm{rpm}$ for $20 \mathrm{~min}$ [28], and the solubilized phosphorus was quantified in the supernatant by the colorimetric method of Olsen and Sommers [29].

\subsubsection{Production of Indole-3-Acetic Acid}

Production of IAA was assessed as described by Wahyudi et al. [21] and modified as follows: Spore suspension of each strain $(100 \mu \mathrm{L})$ was inoculated in NBRIP medium supplemented with tryptophan $(0.2 \% w / v)$ and incubated at $30^{\circ} \mathrm{C}$ for 7 days at $150 \mathrm{rpm}$. After incubation, cultures were then centrifuged at $3000 \mathrm{rpm}$ for $20 \mathrm{~min}$. A total of $1 \mathrm{~mL}$ of supernatant was mixed with $4 \mathrm{~mL}$ of Salkowski's reagent [30]. The mixture was incubated at $37^{\circ} \mathrm{C}$ for $30 \mathrm{~min}$ away from light sources. Optical density was read at $530 \mathrm{~nm}$ and the concentrations of IAA in the samples were calculated using the IAA standard curve [31].

\subsubsection{Production of Hydrocyanic Acid and Ammonia and Enzymatic Activities}

A $100 \mu \mathrm{L}$ spore suspension of each strain was spread on Trypticase Soy Agar (TSA) medium supplemented with glycine $\left(4.4 \mathrm{~g} \mathrm{~L}^{-1}\right)$. A Whatman paper-same diameter as the dish-was soaked in a solution of picric acid $(0.5 \%)$ and sodium carbonate $(2 \%)$, and was placed on top of the agar on each inoculated Petri dish, sealed with parafilm, and incubated at $30^{\circ} \mathrm{C}$ for 7 days. The production of hydrocyanic acid $(\mathrm{HCN})$ was assessed by observing paper color change. A coloring from yellow to orange or brown indicates production of $\mathrm{HCN}$ [32].

The production of ammonia was carried out on peptone water medium; $10 \mathrm{~mL}$ of peptone water was inoculated with $100 \mu \mathrm{L}$ of each spore suspension. After incubation for 7 days at $30^{\circ} \mathrm{C}, 0.5 \mathrm{~mL}$ of Nessler's reagent was added to each tube. Yellow color development was considered as a positive result [33].

Amylase, caseinase, catalase, cellulase, chitinase, gelatinase, lecithinase, lipase, lipoproteinase, and pectinase enzymatic activities were assessed as follows:

- Amylase: Strains were streaked on the Glycerol Bouillon Agar (GBA) medium $\left(20 \mathrm{~g} \mathrm{~L}^{-1}\right.$ soluble starch, $20 \mathrm{~mL} \mathrm{~L}^{-1}$ glycerol, $10 \mathrm{~g} \mathrm{~L}^{-1}$ peptone, $5 \mathrm{~g} \mathrm{~L}^{-1}$ meat extract, $3 \mathrm{~g} \mathrm{~L}^{-1} \mathrm{CaCO}_{3}, 15 \mathrm{~g} \mathrm{~L}^{-1}$ agar- $\mathrm{pH} 7.0 \pm 0.2$ ). The cultures were incubated at $30^{\circ} \mathrm{C}$ for 7 days, and amylase production was detected after immersion of the dishes with a Lugol solution. A positive outcome was underlined by the presence of a clear discoloration zone around the colonies [34].

- Caseinase: Strains were streaked on skim milk agar [35]. After incubation for 7 days at $30{ }^{\circ} \mathrm{C}$, the presence of a clear discoloration zone around the colonies indicates degradation of the casein [36]. 
- Catalase: An isolated colony from ISP2 agar culture was placed on a slide and a few drops of hydrogen peroxide were deposited on the colony. A positive catalase reaction results from the appearance of bubbles after the release of $\mathrm{O}_{2}$ [37].

- Cellulase: Strains were streaked on the ISP2 medium supplemented with $1 \%$ of cellulose. After incubation for 7 days at $30^{\circ} \mathrm{C}$, dishes were immersed in a Congo red solution $(1 \% w / v)$ for $20 \mathrm{~min}$ and then washed with a $\mathrm{NaCl}$ solution $(1 \mathrm{~N})$. A positive reaction is indicated by the development of a clear discoloration zone around the streak [38].

- Chitinase: Strains were streaked on nutrient agar supplemented with $1 \%$ chitin. After 7 days of incubation at $30^{\circ} \mathrm{C}$, the appearance of clear areas around the colonies was considered as a sign of chitinase production.

- Gelatinase: Strains were inoculated in tubes containing nutritive gelatin medium. After an incubation for 21 days at $30^{\circ} \mathrm{C}$, tubes were placed in the refrigerator for $1 \mathrm{~h}$. If the gelatin becomes solid, this means that it was not attacked; if it remains liquid, this means that an extracellular enzyme has hydrolyzed it [39].

- Lecithinase, lipase, and lipoproteinase: Strains were streaked on agar medium containing egg yolk and prepared following the method described by Dellaras [39]. After plate incubation at $30^{\circ} \mathrm{C}$ for 7 days, the presence of the enzymes was assessed as follows: (i) Lecithinase: Appearance of an opaque halo of white-yellowish pearl, with a clear edge under the streak or at the borders; (ii) Lipase: Appearance of an oily and shiny pearly white halo; (iii) Lipoproteinase: Appearance of a clear halo around the streak [40].

- Pectinase: Strains were streaked on MP7 agar [38]; after incubation for 7 days at $30{ }^{\circ} \mathrm{C}$, the dishes were flooded with a solution of $\mathrm{Cu}$-acetate at $10 \%$ for $15 \mathrm{~min}$. The appearance of a clear halo indicates the presence of pectinolytic activity [41].

\subsection{In Vitro Association Study by Scanning Electron Microscopy}

Spore suspensions of each strain $\left(10^{6}\right.$ spores $\left.\mathrm{mL}^{-1}\right)$ were used to inoculate in vitro seedlings to assess the ability of the actinomycetes to colonize plant roots [42]. Tomato seeds (Solanum lycopersicum) of the Saint Pierre variety were utilized for the experiments.

To stimulate germination, seeds were put in sterile distilled water for $24 \mathrm{~h}$. Then, they were sterilized on a $20 \%(w / v)$ sodium hypochlorite solution $(\mathrm{NaClO})$ for $15 \mathrm{~min}$ in a shaker, followed by several washes in sterile distilled water. Seeds were then treated in ethanol at $70 \%(w / v)$ for $3 \mathrm{~min}$ and, finally, rinsed three times with distilled water for $15 \mathrm{~min}$ [43].

Inoculation of seeds was obtained by $1 \mathrm{~h}$ of immersion in the inoculum. Control seeds were treated with the same procedure but using sterile distilled water.

Inoculated and non-inoculated seeds were transferred into culture boxes containing $50 \mathrm{~mL}$ of MS medium-Murashige and Skoog [44] — containing 1\% agar and 3\% sucrose at a final pH of 5.8, and incubated in a growth chamber with a controlled environment $\left(22^{\circ} \mathrm{C}\right.$, photoperiod $16 \mathrm{~h}$ light and $8 \mathrm{~h}$ dark, active photo-synthetical radiation $120 \mu \mathrm{mol} \mathrm{m}^{-2} \mathrm{~s}^{-1}, 65 \%$ relative humidity).

After 8 days, the fresh seedling roots were sampled and sections of $5 \mathrm{~mm}$ diameter were prepared. A solution of $2.5 \%$ glutaraldehyde in $0.2 \mathrm{M}$ cacodylate buffer ( $\mathrm{pH} 7.2-7.4$ ) was used to fix sections. After fixation at $4{ }^{\circ} \mathrm{C}$ for $24 \mathrm{~h}$, the excised sections were dehydrated in $70 \%$ and $100 \%$ ethanol $(20 \mathrm{~min}$ for every treatment) and treated with Hexamethyldisilazane (HMDS) [42]. The dried samples were covered with chromium, and the observations were carried out with scanning electron microscopy (SEM) under the conditions previously described in Pagnani et al. [42].

\subsection{Greenhouse Experiment on Solanum Lycopersicum}

The fourteen selected actinomycete strains were inoculated on tomato seeds (Solanum lycopersicum) of the Saint Pierre variety. The seed surface was sterilized with a sodium hypochlorite solution $20 \%$ $(v / v)$ and washed several times with sterile distilled water [45]. 
The inoculation was carried out by dipping the seeds in the different spore suspensions $\left(10^{6} \mathrm{~mL}^{-1}\right)$ for $1 \mathrm{~h}$; seeds immersed in sterile distilled water were used as a control. Inoculated and uninoculated seeds were sown in pots $(\Phi=10 \mathrm{~cm})$ filled with soil $\left(\mathrm{pH} 7.9\right.$, electrical conductivity $332 \mu \mathrm{S} \mathrm{cm}{ }^{-1}$, $5 \%$ organic matter, and $0.7 \%$ humidity rate) and were irrigated with tap water twice a week.

Forty days after sowing (DAS), plants were sampled, collecting shoots and roots separately. The following parameters were investigated: Lengths, fresh weight, dry weight (oven drying at $105^{\circ} \mathrm{C}$ for $48 \mathrm{~h}$ ), ash-free dry weight (AFDW), and chlorophyll contents.

AFDW was determined by subtracting dry weight from the ashes' weight (obtained using a muffle furnace at $450{ }^{\circ} \mathrm{C}$ for $16 \mathrm{~h}$ ) as follows:

$$
\text { AFDW }(\%)=\frac{\text { dry weight }- \text { ashes weight }}{\text { dry weight }} \times 100 \text {. }
$$

Chlorophyll a $\left(\mathrm{Chl}_{\mathrm{a}}\right)$, chlorophyll b $\left(\mathrm{Chl}_{\mathrm{b}}\right)$, and total chlorophyll $\left(\mathrm{Chl}_{\text {tot }}\right)$ contents were determined following the method described by Arnon [46]. Briefly, $0.5 \mathrm{~g}$ of leaves from each sample, finely cut, were homogenized in $10 \mathrm{~mL}$ of acetone $80 \%$ and stored at $-10{ }^{\circ} \mathrm{C}$ overnight; after centrifugation at $14,000 \mathrm{rpm}$ for $5 \mathrm{~min}$, supernatant absorbance was read at 663 for chlorophyll a and at $645 \mathrm{~nm}$ for chlorophyll b. The chlorophyll concentrations in the samples were calculated through the following equations:

$$
\begin{gathered}
\mathrm{Chl}_{\mathrm{a}}\left(\mathrm{mg} \mathrm{L}^{-1}\right)=12.41(\mathrm{OD} 663)-2.59(\mathrm{OD} 645) \\
\mathrm{Chl}_{\mathrm{b}}\left(\mathrm{mg} \mathrm{L}^{-1}\right)=22.9(\mathrm{OD} 645)-4.68(\mathrm{OD} 663) \\
\mathrm{Chl}_{\mathrm{tot}}\left(\mathrm{mg} \mathrm{L}^{-1}\right)=\mathrm{Chl}_{\mathrm{a}}+\mathrm{Ch}_{\mathrm{b}} .
\end{gathered}
$$

\subsection{Statistical Analysis}

Each experiment was carried out in triplicate, and data are presented as mean \pm standard deviation. Data were analyzed by one-way analysis of variance (ANOVA), utilizing Tukey's Honestly Significant Difference (HSD) post-hoc test to compare the mean values to a significance level of 5\% $(p<0.05)$. ANOVA was performed using Statistica 10.0 software (Dell Software, Round Rock, TX, USA). To evaluate potential correlations among the IAA, phosphate solubilization, and HCN traits showed in vitro and the plant-growth parameters recorded in the greenhouse experiment, the dataset was processed by the Principal Component Analysis (PCA) algorithm using XLSTAT 2014 software (Addinsoft, Paris, France).

\section{Results and Discussion}

\subsection{Plant-Growth-Promoting Traits}

To assess the potentiality of any strain to be used as biostimulant and/or biocontrol agent, it is necessary to establish its plant-growth-promoting (PGP) traits. In our study, different PGP tests were performed to select promising strains-among the sixty isolates-to improve plant growth and development. In Figure 1, the graphic summary of the results obtained by PGP tests is shown. 


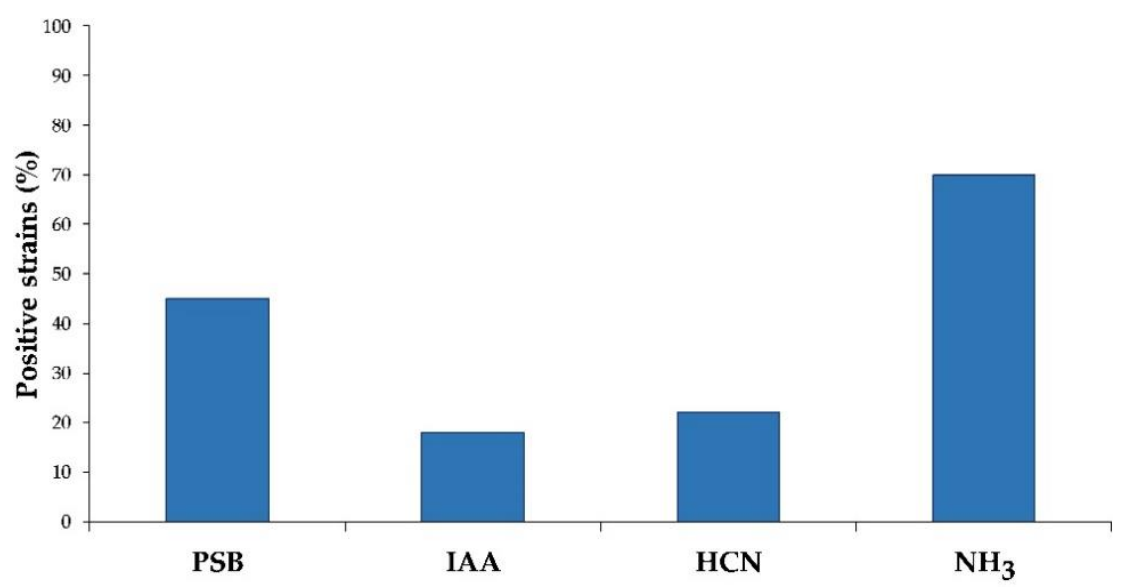

Figure 1. Frequencies of strains (\%) that showed plant-growth-promoting traits. In the figure, the percentages of phosphate-solubilizing bacteria (PSB) and of strains producing IAA (indole-3-acetic acid), hydrocyanic acid $(\mathrm{HCN})$, and ammonia $\left(\mathrm{NH}_{3}\right)$ are shown.

Most of the strains ( $70 \%$ ) were able to produce ammonia, $45 \%$ were able to dissolve inorganic phosphate, $18 \%$ were able to produce IAA, and $22 \%$ were able to produce $\mathrm{HCN}$.

Based on these results, among the 60 strains tested, 14 strains were selected as promising PGPB:

- $\quad$ D14, Nocardiopsis dassonvillei subsp. dassonvillei (Gene Bank accession MG597514).

- G10, Streptomyces iakyrus (MG597593).

- G22, Streptomyces xantholiticus (MG597582).

- $\quad$ G33, Streptomyces xantholiticus (MG597585).

- H12, Streptomyces albidoflavus (MG597552).

- H14, Nocardiopsis aegyptica (MG597543).

- J4, Streptomyces thinghirensis (MG597590).

- J13, Streptomyces anulatus (MG597579).

- J21, Nocardiopsis alba (MG597576).

- $\quad \mathrm{J} 27$, Streptomyces ambofaciens (MG597599).

- $\mathrm{K} 12$, Streptomyces xantholiticus (MG597545).

- K23, Streptomyces thinghirensis (MG597560).

- $\quad$ S2, Nocardiopsis aegyptica (MG597572).

- $\quad$ T45, Nocardiopsis dassonvillei subsp. dassonvillei (MG597502).

These isolates tolerated up to $10 \% \mathrm{NaCl}$ during in vitro testing, suggesting halotolerant traits [25].

\subsubsection{Phosphate Solubilization}

The solubilization of phosphate on solid media was revealed by the presence of a discoloration zone around the strain colonies. Among the fourteen strains, phosphate solubilization was observed in twelve of them. The diameters recorded for these PSB are shown in Figure 2. Strain solubilization capability was different based on culture medium. On PVK medium, most of the strains showed solubilization capability (79\%). In this medium, strain K23 showed the largest solubilization diameter $(16 \mathrm{~mm})$. On NBRIP medium, ten strains $(71 \%)$ showed this capability, and the maximum diameter $(20 \mathrm{~mm}$ ) was observed for strains H14 and J21. The diameters shown by our strains were wider than those reported in similar studies [47,48], but still in line with what was reported by several authors for NBRIP and PVK media [49,50]. On LB medium, only one strain (J27) had a solubilization halo, with a diameter of $2 \mathrm{~mm}$. This result could be due either to the LB's richness in nutrients, which does not allow bacteria to solubilize inorganic phosphorus [26], or to the fact that bacteria do not need phosphate because it is already present in the medium in a more easily assimilable form. 


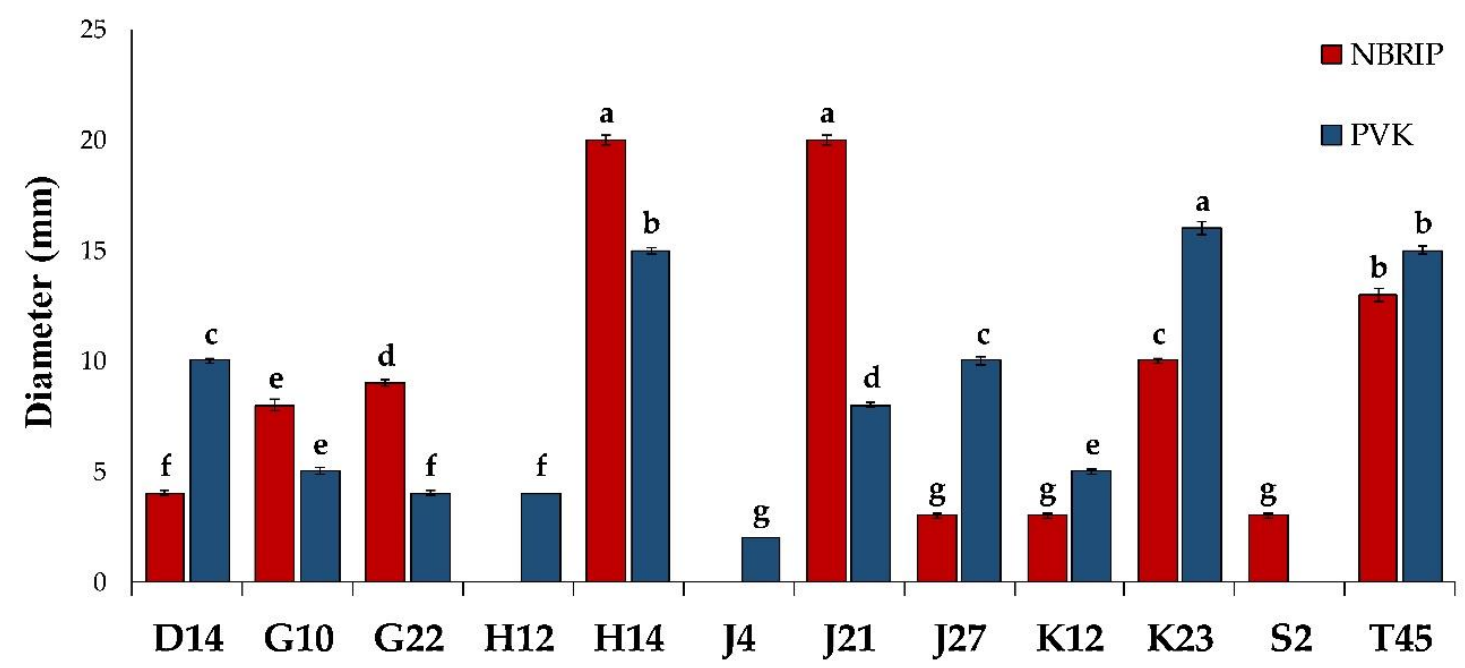

Figure 2. Halo diameters of phosphate solubilization by the actinomycete strains on solid National Botanical Research Institute's Growth Medium (NBRIP) and Pikovskaya (PVK) media. For the same medium (NBRIP or PVK), results followed by the same case letter are not significantly different according to Tukey's HSD post-hoc test $(p>0.05)$.

In Figure 3, the amounts of phosphorus solubilized by the fourteen strains grown in PVK liquid medium are shown. The highest solubilization was obtained by strain D14 $\left(24.84 \mu \mathrm{g} \mathrm{PO}_{4}{ }^{3-} \mathrm{mL}^{-1}\right.$, $p<0.05)$; lower but similar results were obtained for G22 $\left(23.25 \mu \mathrm{g} \mathrm{PO}_{4}{ }^{3-} \mathrm{mL}^{-1}\right)$ and H14 $(22.2 \mu \mathrm{g}$ $\left.\mathrm{PO}_{4}{ }^{3-} \mathrm{mL}^{-1}\right)$ strains. The lowest solubilization rate was recorded for the $\mathrm{J} 13$ strain $\left(9.89 \mu \mathrm{g} \mathrm{PO}_{4}{ }^{3-}\right.$ $\left.\mathrm{mL}^{-1}, p<0.05\right)$.

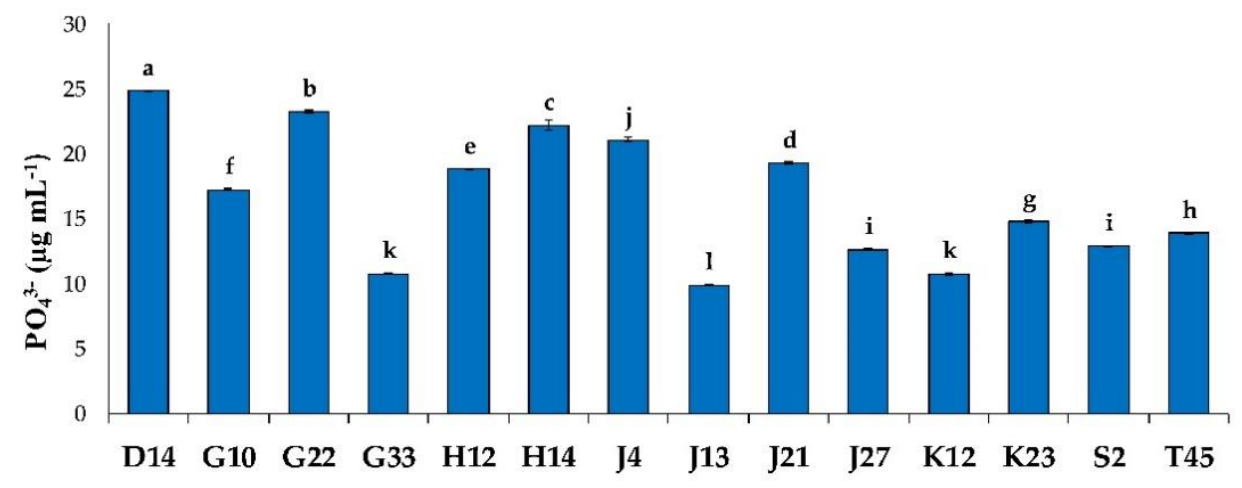

Figure 3. Concentrations of phosphate $\left(\mathrm{PO}_{4}{ }^{3-}\right)$ solubilized by actinomycete strains grown on liquid PVK medium. Results followed by the same case letter are not significantly different according to Tukey's HSD post-hoc test ( $p>0.05)$.

On solid PVK medium, only 11 strains (D14, G10, G22, H12, H14, J4, J21, J27, K12, K23, and T45) were able to produce a solubilization halo around the colony ( 2 to16 $\mathrm{mm}$ in diameter), while all the other strains were able to solubilize phosphate on a liquid medium. These results indicate that, despite the absence of a solubilization halo around the colonies by G33, J13, and S2 on solid medium, they can solubilize phosphate at considerable rates on liquid PVK medium. This absence of correlation between solid and liquid PVK solubilization was also statistically confirmed by a correlation test. A weak negative association was obtained $(r=-0.27)$, suggesting that liquid medium solubilization is a more reliable technique compared to the solid one [26]. The ability to use $\mathrm{Ca}_{3}\left(\mathrm{PO}_{4}\right)_{2}$ is also important for phytohormone production and, thus, for indirectly improving plant growth [31]. Another rhizosphere microbial mechanism of mineral phosphate solubilization is related to the release of low molecular weight organic acids, which chelate cations to bind phosphates through their hydroxyl and carboxyl groups. Therefore, these isolates have the potential to mobilize insoluble inorganic phosphate under 
low phosphate availability [31]. PGP strains that are able to solubilize inorganic phosphate and make the organic forms available for plant absorption [23,51] have a positive outcome on plant growth [18]. Our findings are consistent with those obtained by several authors [49,52].

\subsubsection{Production of Indole-3-Acetic Acid}

In Figure 4, the IAA production by the different strains is shown. Among the fourteen actinomycetes, nine strains (64\%) showed the ability to synthesize IAA. Variable production rates were also detected; the highest amounts of IAA were observed for strain H14 $(21.4 \mu \mathrm{g} / \mathrm{mL}, p<0.05)$, followed by the T45 $(14.75 \mu \mathrm{g} / \mathrm{mL}), \mathrm{G} 22(12.37 \mu \mathrm{g} / \mathrm{mL})$ and G10 $(12.25 \mu \mathrm{g} / \mathrm{mL})$ strains. The lowest production was observed for strains G33 and K12 (7.44 $\mu \mathrm{g} \mathrm{mL}-1, p<0.05)$.

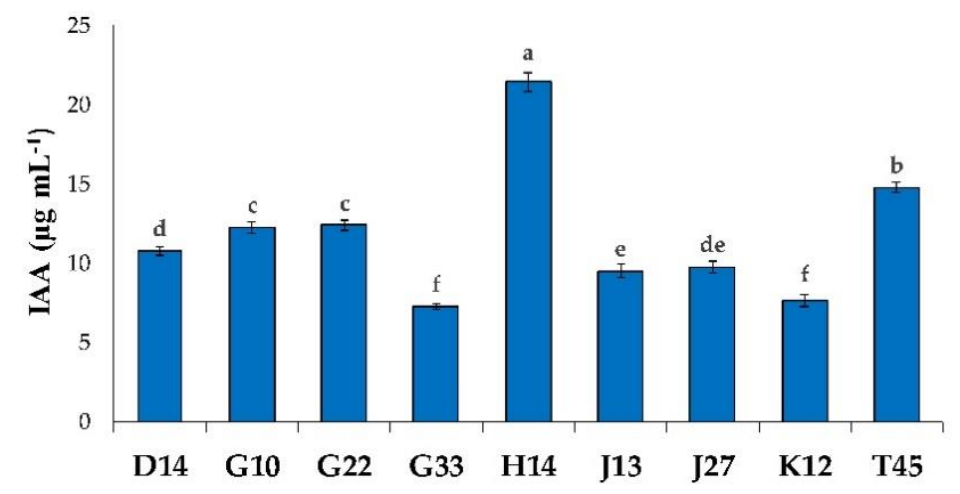

Figure 4. Concentrations of indole-3-acetic acid (IAA) produced by the selected actinomycete strains. Results followed by the same case letter are not significantly different according to Tukey's HSD post-hoc test $(p>0.05)$.

IAA is a plant-growth-promoting substance that acts through different metabolic pathways $[18,19]$; it is involved in root elongation, cell division, and proliferation of root hairs [21,53,54]. Among its different effects, it stimulates seed germination, seedling length, and dry weight, and it is produced by many PGPB $[19,23,55,56]$. About $80 \%$ of rhizobacteria are capable of producing indole-3-acetic acid (IAA) as a secondary metabolite [57]. L-tryptophan is a precursor of IAA production; thus, its addition to cultural medium generally promotes and increases its synthesis by the bacterium [57]. In natural conditions, this amino acid is supplied by root exudates [58]. Many studies suggest that small amounts of IAA are necessary for the primary roots' growth $[55,59]$ and that bacteria with the ability to secrete amounts of indole compound higher than $13.5 \mu \mathrm{g} \mathrm{mL} \mathrm{L}^{-1}$ have PGP activity. Several species of actinomycetes have been reported to produce IAA [23], which is influenced by the culture conditions, the growth phase, and the availability of substrate [60]. Our results are in accordance with the data present in the literature $[21,31,50,61,62]$, suggesting that the selected strains are good candidates as biostimulant agents.

\subsubsection{Production of Hydrocyanic Acid, Ammonia, and Enzymatic Activities}

Hydrocyanic acid production, ammonia, and several enzymatic activities are shown in Table 1. 
Table 1. Hydrocyanic acid, ammonia production, and enzymatic activities detected for the actinomycete strains.

\begin{tabular}{cccccccccccccccc}
\hline & K12 & K23 & H12 & H14 & S2 & D14 & T45 & J4 & J13 & J21 & J27 & G10 & G22 & G33 \\
\hline HCN & + & + & + & + & + & - & - & + & + & + & + & + & - & + \\
$\mathrm{NH}_{3}$ & + & + & + & + & + & + & + & + & + & + & + & + & + & + \\
Amylase & + & + & + & + & + & + & + & + & + & + & + & - & + & + \\
Caseinase & + & + & - & + & + & + & + & + & + & + & + & + & + & + \\
Catalase & + & + & + & + & + & + & + & + & + & + & + & + & + & + \\
Cellulase & - & + & - & + & - & - & + & + & + & + & + & + & + & - \\
Chitinase & - & - & - & - & - & - & - & - & - & - & - & + & - & - \\
Gelatinase & + & + & + & + & + & + & + & + & + & + & + & + & + & + \\
Lecithinase & - & + & - & - & + & - & - & + & + & + & - & + & - & + \\
Lipase & - & - & - & + & - & - & + & - & - & - & - & - & - & + \\
Lipoprotease & - & + & + & + & + & + & + & + & + & + & + & - & - & + \\
Pectinase & + & + & - & + & + & + & - & + & + & + & - & + & + & + \\
\hline
\end{tabular}

HCN production was detected only in eleven of the tested isolates, while the capability to produce ammonia was expressed for all fourteen strain. For strains D14, G22, and T45, no cyanogenic activity was observed. Instead, intense HCN production was shown by G10, G33, H12, J4, J13, J27, K12, $\mathrm{K} 23$, and S2 strains. Our findings are comparable with the data present in the literature $[56,63,64]$. These volatile compounds, in such a low amount, can help the plant to counteract phytopathogens and stimulate its growth $[56,65]$. HCN is an inducer of plant resistance [64] that interferes with the cytochrome oxidase pathway, with toxic effects on sensitive pathogen microorganisms [65].

Many authors report ammonia production as a PGP trait [66], and it has been correlated with plant root and shoot elongation and increasing plant biomass $[67,68]$. Ammonia also participates in organic matter decomposition, resulting in higher plant productivity and higher phytoparasite tolerance [67]. However, high ammonia emission by rhizobacteria is toxic for the plant [69], and ammonia production should be considered, instead, as a negative trait, unless it is transformed into $\mathrm{NO}_{2}{ }^{-}$and then into $\mathrm{NO}_{3}{ }^{-}$by nitrifying bacteria. Anyway, proteins that allow bacteria to produce ammonia are infrequent in the rhizosphere, or are present in a very low amount, while nitrifying bacteria are usually present in the soil.

The different enzymatic activities of the fourteen actinomycete strains are shown in Table 1. All of the tested strains showed significant enzymatic activities of catalase, cellulase, amylase, proteases, pectinase, lipases, and chitinase by means of in vitro tests (examples of the outcomes of some enzymatic activities tests are shown in Figure 5). These results, although not always directly related to the PGP traits, show some characteristics that can be biotechnologically interesting and of significant commercial value. Among the indirect mechanisms of plant growth promotion, the production of enzymes is a key function in the prevention of plant infection caused by pathogens [70]. The presence of hydrolytic enzymes also plays an important role in soil fertility by degrading complex polysaccharides and proteins into simpler forms. The latter are given back to the soil, increasing its fertility status [50,71]. Catalase, detected in all strains (Table 1), protects cells against oxidative damages caused by reactive oxygen species (ROS) by catalyzing the decomposition of hydrogen peroxide into water and oxygen. Catalase confers to the bacterium a good resistance to various environmental mechanical and chemical constraints [64,72], giving an ecological advantage. Amylases are thermostable enzymes that contribute to the degradation of soil organic matter, plant residues, and composting, speeding up the process [71]. Microbial proteases contribute to recycling organic matter in soil and play an important role in the interactions among soil microbial communities through cell wall protein cleavage [73,74]. Pectinases are essential for the decomposition of plant residues, contributing to the recycling of carbon compounds in the soil. Pectinolytic enzymes improve root invasion by bacteria, playing an indispensable role in plant-microbe interactions [75]. Strain G10 is the only one capable of degrading chitin. Chitinases inhibit fungal growth by hydrolyzing chitin, which is the major component of the fungal cell wall [66]. These enzymes are very important for biotechnological purposes: They are used in the engineering of 
plants that are resistant to phytopathogens and they can be used also in seed preservation [76]. Lipases are widely distributed among microorganisms and are of great industrial importance [77]; triglyceride hydrolysis can significantly contribute to the composting of sewage sludges [71].
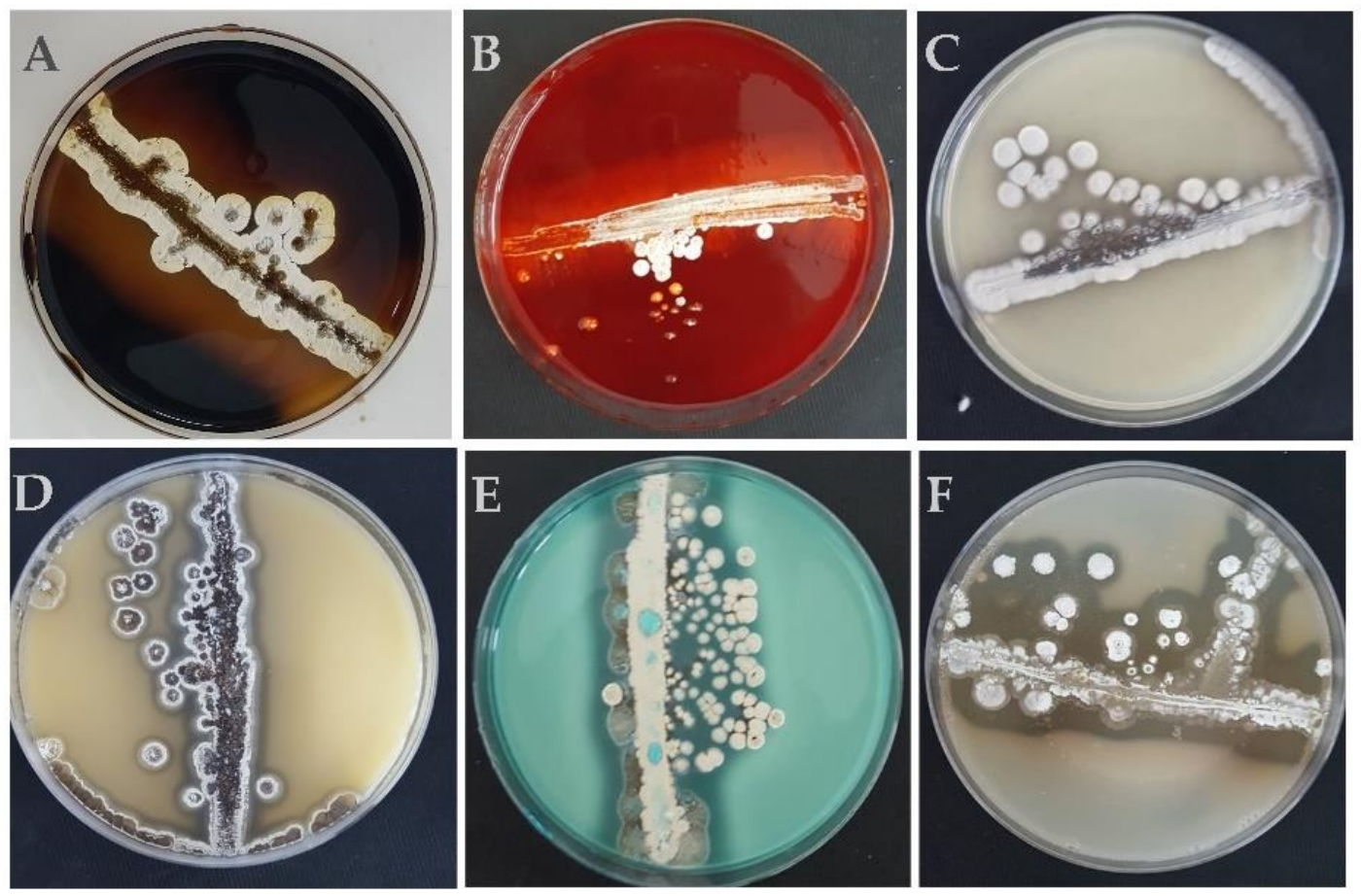

Figure 5. Agar-plate-based (90 mm diameter plates) screening carried out for amylase (A), cellulase (B), chitinase (C), lecithinase (D), pectinase (E), and caseinase (F) enzymatic activities.

\subsection{In Vitro Association Study by Scanning Electron Microscopy (SEM)}

Bacterial root colonization can be properly analyzed by SEM. This procedure allows the understanding of some ecological aspects of the interactions among bacteria and host plants, as well as rhizocompetence and colonization dynamics inside root tissues.

Association abilities were underlined for all strains by SEM investigation. In Figure 6, one can observe the SEM micrographs of the control roots (not inoculated) together with roots inoculated with G10—Streptomyces iakyrus (MG597593)—and H14—Nocardiopsis aegyptica (MG597543)—strains. These two strains were chosen over the others, as they recorded the best growth rates during in vitro cultivation of S. lycopersicum. In addition, they are representative of the two genera to which the other strains belong.

The control (Figure 6A,D) shows clean surfaces (indicator of aseptic conditions), while the G10 and H14 strains' association on root cell walls was evident at different magnifications (Figure 6B,E and 6C,F, respectively). Seedlings inoculated with strain G10, colonized by clusters of agglomerated spores (Figure 6B,E), showed remarkable growth in comparison with uninoculated controls. In the case of the sample inoculated with strain H14, the presence of spores of various lengths, dispersed along the surfaces of the seedlings (Figure 6C,F), was evident. Our findings are similar to those obtained by Sreevidya and collaborators [62], who reported the ability of four Streptomyces strains to grow and adhere to chickpea root surfaces. Regarding Nocardiopsis, as far as we know, the present study is the first report describing root association ability in in vitro seedlings. Root association ability is a basic characteristic generally attributed to strains with PGP traits [44,78]. Plant-bacteria associations are facilitated by root exudates (i.e., aromatic and phenolic compounds, sugars, amino acids, organic acids, and carbohydrates), which behave as chemo-attractants for microorganisms, helping in root colonization [62]. Actinomycetes, like other PGPB, have the ability to adhere to plant roots and to produce different compounds that protect the host plant against biotic and abiotic stress [62]. Beyond 
the production of auxins, gibberellins, and cytokinins [5], which promote plant growth, PGPB release quorum sensing signals. These molecules promote the synthesis of antimicrobial substances that can protect the plant against possible pathogens present in the soil [79].
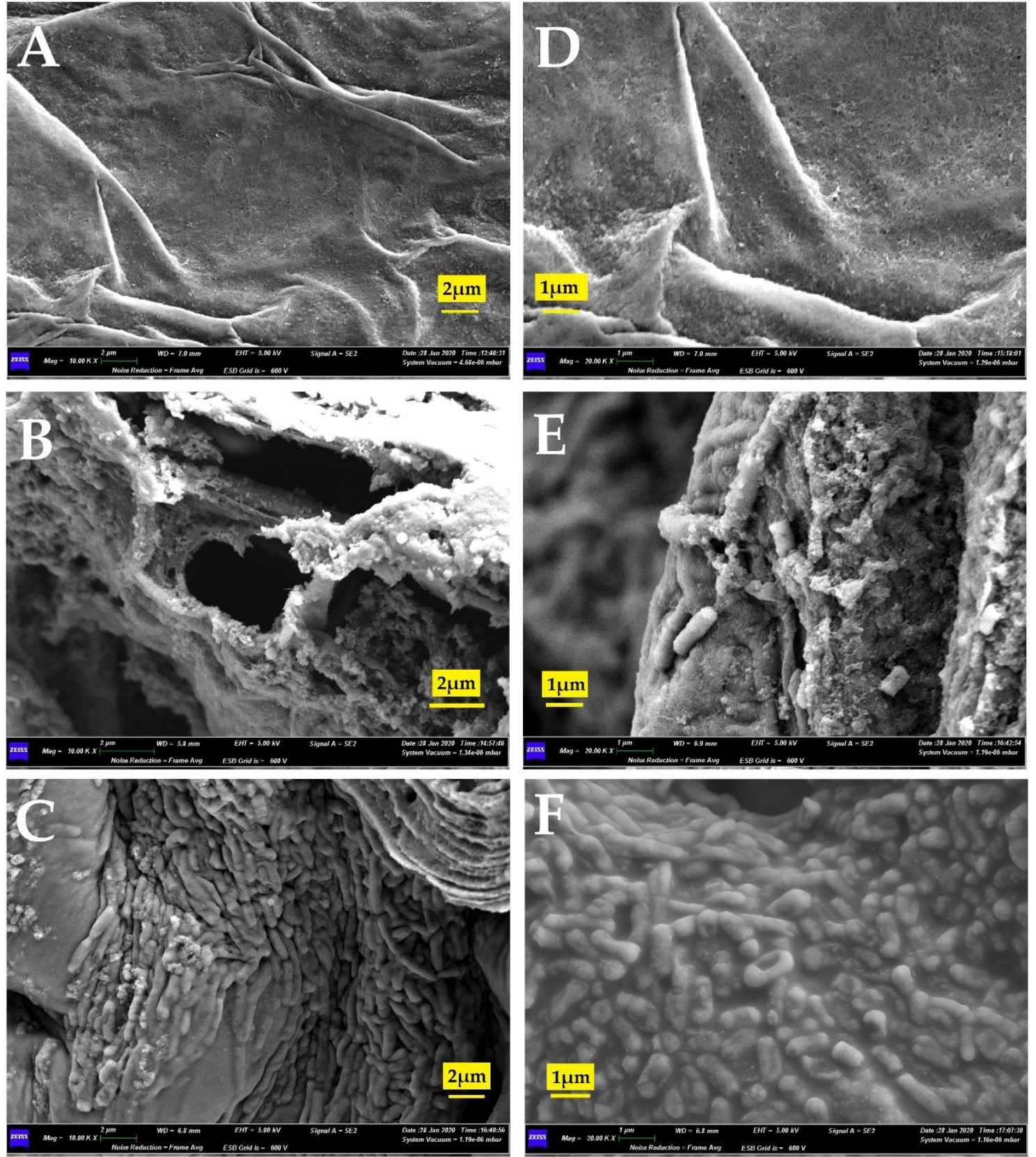

Figure 6. Micrographs under scanning electron microscopy of fresh roots obtained from eight-day seedlings of Solanum lycopersicum not inoculated and inoculated with strains G10 and H14. The control sample (A,D) shows clear surfaces at $10 \mathrm{~K}$ and $20 \mathrm{~K}$ of magnification. On the contrary, microbial colonization is evident at $10 \mathrm{~K}$ of magnification in seedlings inoculated with G10 (B) and H14 strains (C). At 20K, G10 (E) and H14 (F) dispersed spores of various lengths.

\subsection{Greenhouse Experiment on Solanum Lycopersicum}

Tomato seeds were also inoculated with the different strains in a pot greenhouse experiment, and plants were collected at 40 DAS. The results obtained on shoot and root lengths and AFDW for the inoculated plants (D14-T45) and for the control plants (CNT) are shown in Figure 7. 


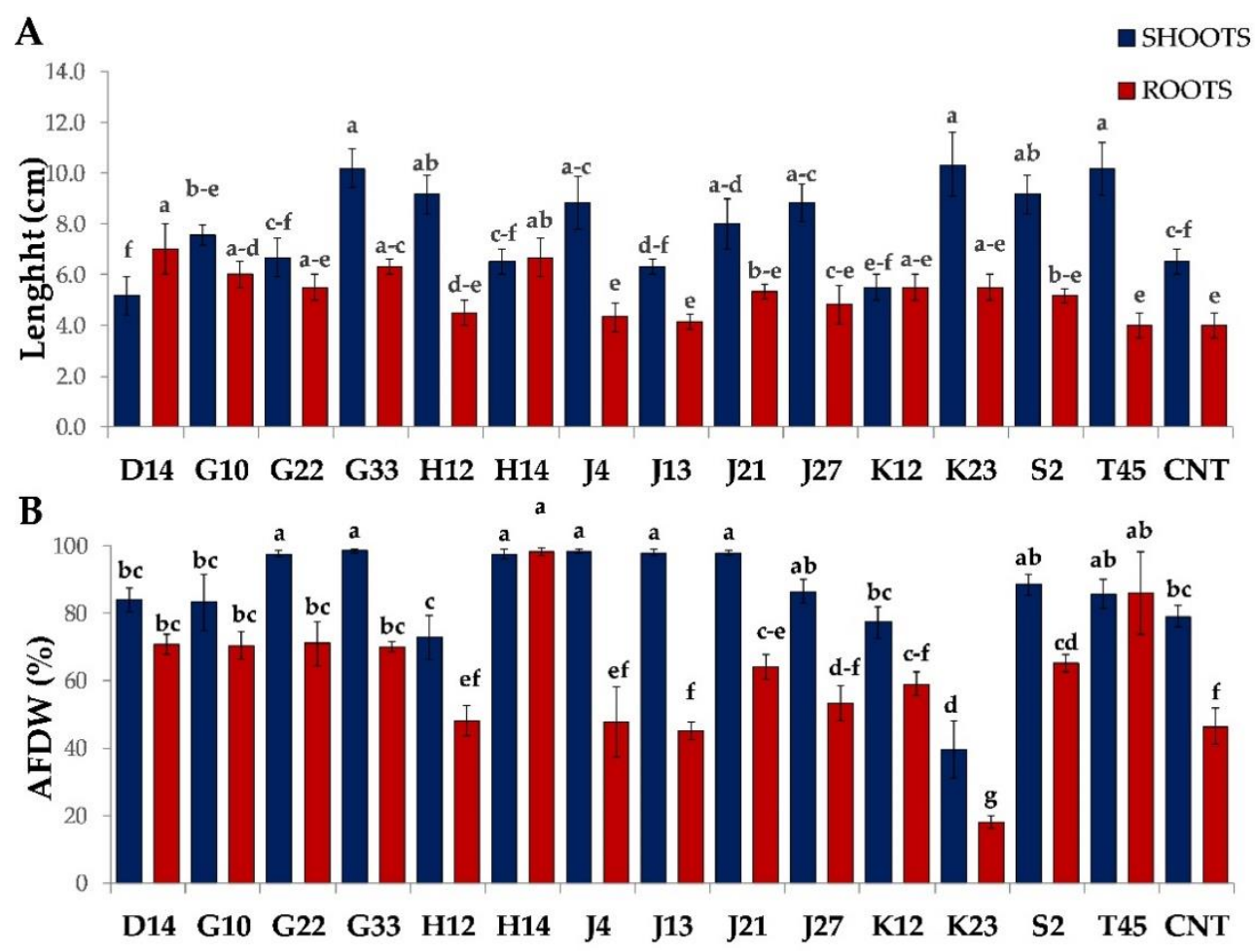

Figure 7. Shoot and root length (A), ash-free dry weight (AFDW) (B) of shoots and roots of tomato plants (Solanum lycopersicum). Results followed by same case letters are not significantly different according to Tukey's HSD post-hoc test $(p>0.05)$.

Inoculation with actinomycete strains showed variable effects on lengths and AFDW of shoots and roots. The stimulation of these parameters was different according to the inoculated strain. Shoot lengths of plants inoculated with K23, G33, T45, H12, and S2 strains recorded the highest values $(p<0.05)$, with a shoot length increase of $51 \%$ on average with respect to the control. Regarding shoot AFDW, the highest percentages were recorded for plants inoculated with G33, J4, J21, J13, G22, and H14 strains $(p<0.05)$. Compared to the control, for these samples, the AFDW increased $24 \%$ on average. The lowest AFWD percentages were recorded for K23 $(p<0.05)$. Similar trends were underlined by root lengths and AFDW: The best lengths were recorded with strains D14, H14, G33, and G10, and the best AFDW was recorded in plants inoculated with strains H14, T45, G22, D14, G10, G33, S2, and J21 $(p<0.05)$. In these plants, the increase with respect to the control was $63 \%$ and $61 \%$ for root lengths and AFDW, respectively. For AFDW, plants inoculated with strain K23 recorded, once again, the lowest values $(p<0.05)$.

Plant shoots were also investigated for their chlorophyll a $\left(\mathrm{Chl}_{\mathrm{a}}\right)$, chlorophyll $\mathrm{b}\left(\mathrm{Chl}_{\mathrm{b}}\right)$, and total chlorophyll $\left(\mathrm{Chl}_{\text {tot }}\right)$ contents, whose results are shown in Figure 8. Inoculation with actinomycete strains significantly improved shoot chlorophyll contents of inoculated plants with respect to the control $(p<0.05)$. Different results were obtained on chlorophyll contents depending on the inoculated strain. The highest contents $(p<0.05)$ of $\mathrm{Chl}_{\mathrm{a}}$ were observed in samples inoculated with strains G10, T4,5 and G22 (statistically similar to each other, $p>0.05$ ). Strain G10 also significantly improved $\mathrm{Chl}_{\mathrm{b}}$ contents $(p>0.05)$ in the shoot, resulting in higher contents of $\mathrm{Chl}_{\text {tot }}$ compared to the other strains $(p>0.05)$. These findings clearly show that actinomycete inoculation positively affects plant morpho-physiological characteristics. Among the PGP traits previously underlined for these strains, IAA production plays an important role in growth promotion. This hormone is recognized to stimulate cell elongation-with consequent promotion of plant development-and chlorophyll content. Our results are in agreement with what was previously reported by other authors for Streptomyces. The study of Sreevidya and collaborators [62], for example, reported that different Streptomyces strains increased plant growth parameters of inoculated chickpeas. 


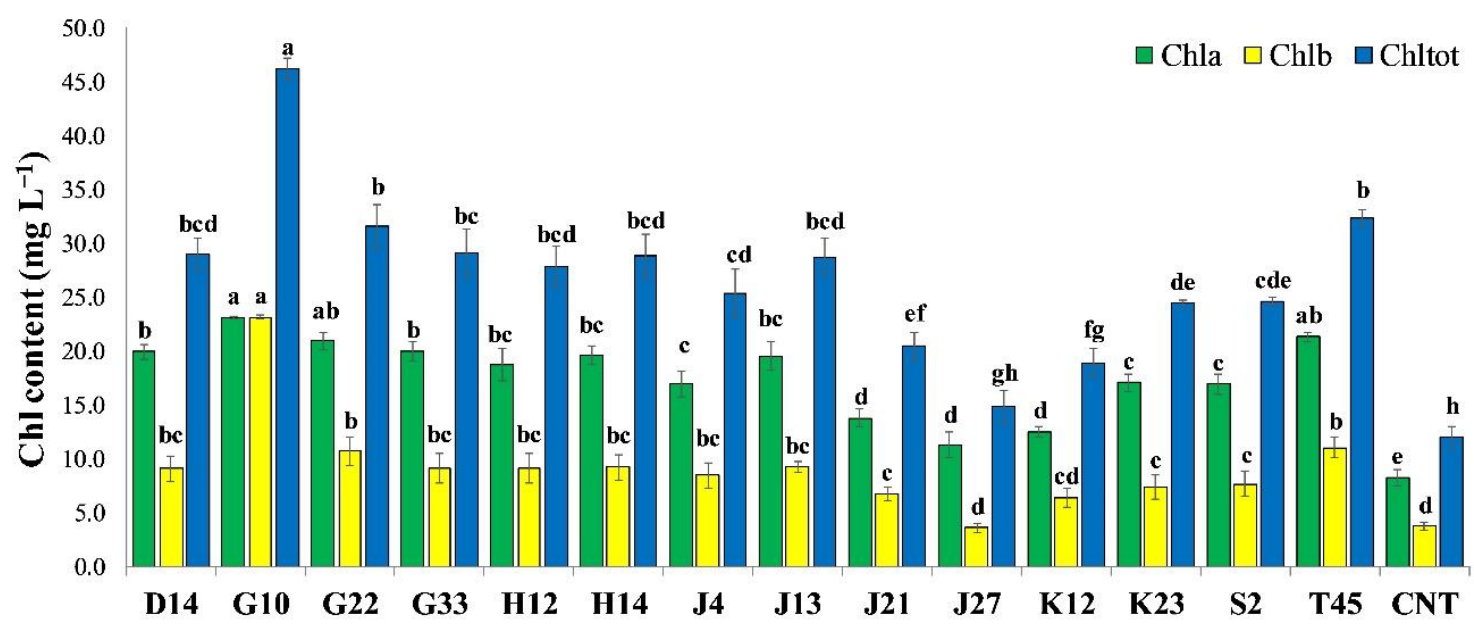

Figure 8. Contents of chlorophyll a $\left(\mathrm{Chl}_{\mathrm{a}}\right)$, chlorophyll b $\left(\mathrm{Chl}_{\mathrm{b}}\right)$, and total chlorophyll $\left(\mathrm{Chl}_{\text {tot }}\right)$ on Solanum lycopersicum not inoculated (CNT) and inoculated with the selected actinomycete strains. Results followed by same case letter are not significantly different according to Tukey's HSD post-hoc test $(p>0.05)$.

Few studies have been directed to the study of Nocardiopsis, among which the recent work of Patel and Thakker [80] reported positive effects on growth and developmental parameters of pearl millet. As far as we know, the present work is the first that reports the inoculation of Nocardiopsis on tomato plants.

To explore potential correlations among IAA production, phosphate solubilization, and HCN release traits shown in vitro, as well as the plant growth parameters recorded in the in planta experiment, a dataset was processed by the PCA algorithm. Figure 9 reports the PCA biplot obtained for the different traits and plant growth parameters (loadings) obtained for the fourteen strains (scores). The total variance explained was $61.65 \%$, with the first component (PC1) accounting for $39.11 \%$ and the second (PC2) for 22.53\%. From the PCA biplot, different groupings based on correlations among traits and parameters are evident. AFDWs of shoots and roots and root length obtained by strains D14, G22, and H14, are correlated with IAA and phosphate solubilization. Chlorophyll contents promoted by the inoculation with the G10 strain are also positively influenced by IAA and phosphate solubilization capability (same positive correlation on PC1), as well as HCN (same positive correlation on PC2). The shoot elongation promoted by strains K23, H12, G33, and T45 is positively correlated with HCN production. These good correlations between in vitro and in planta results demonstrate that our in vitro approach allowed the selection of biostimulant strains that are also effective in natural conditions. As previously discussed, these traits are usually recognized to have positive effects on plant growth and development. 


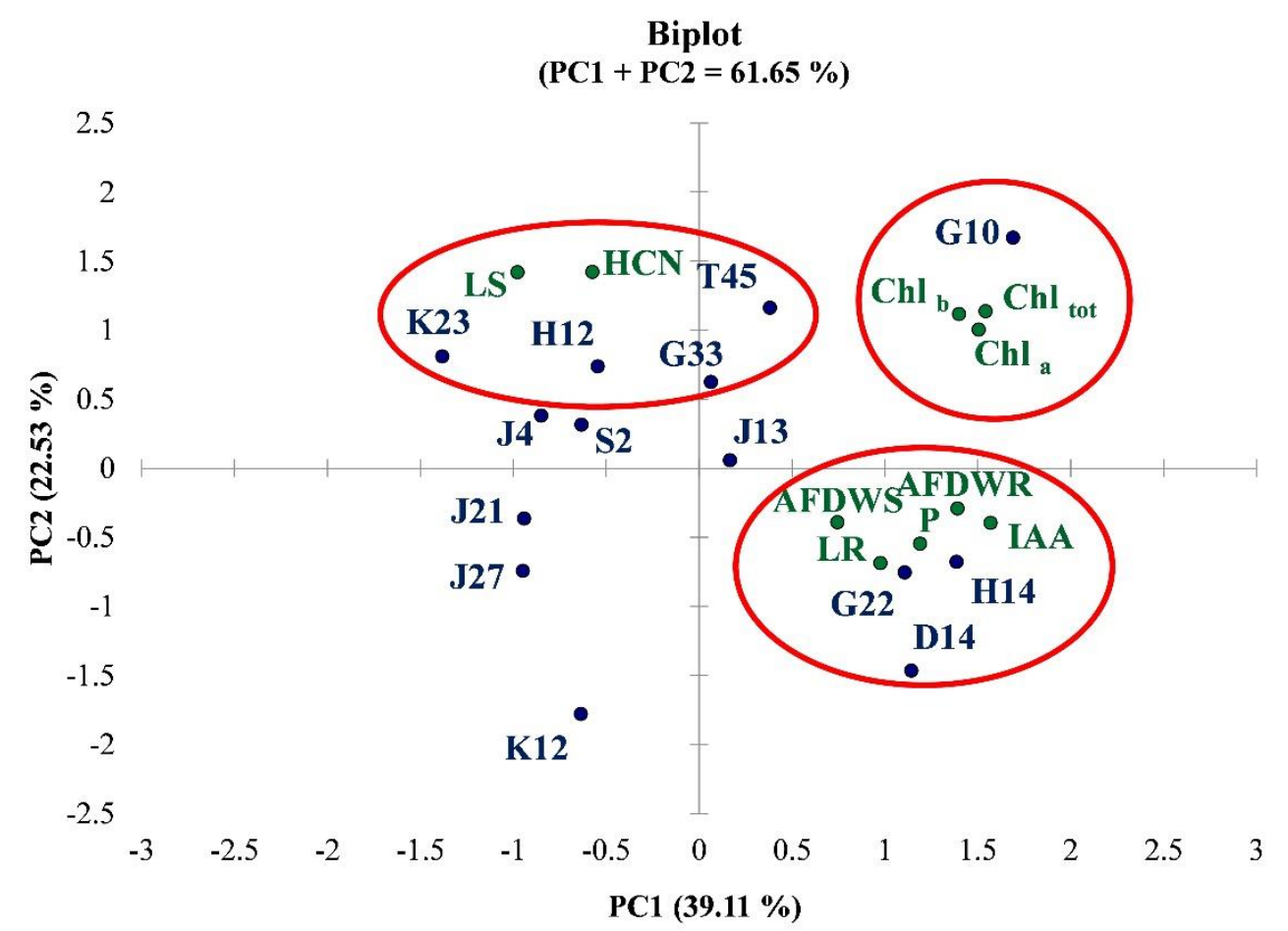

Figure 9. Biplot obtained from the PCA on the dataset of in vitro and in planta results (loadings) recorded for actinomycete strains (scores). In the figure: $\mathrm{Chl}_{\mathrm{a}}$, chlorophyll $\mathrm{a}$; $\mathrm{Ch}_{\mathrm{b}}$, chlorophyll b; $\mathrm{Chl}_{\text {tot }}$, total chlorophyll; HCN, hydrocyanic acid; LS, length of shoots; LR, length of roots; AFDWR, ash-free dry weight of roots; AFDWS, ash-free dry weight of shoots; P, phosphate solubilization; IAA, indole-3-acetic acid.

\section{Conclusions}

The present study allowed the selection of fourteen PGPB based on their plant-growth-promoting traits among sixty actinomycetes previously isolated in two Algerian sites. The strains G10-Streptomyces iakyrus (MG597593)—and H14-Nocardiopsis aegyptica (MG597543)—showed the best biostimulation abilities during in vitro cultivations of Solanum lycopersicum. Observations by scanning electron microscopy underlined the good association capabilities of these strains with seedling roots. Pot greenhouse cultivations of Solanum lycopersicum showed that inoculation with the fourteen selected actinomycetes enhanced plant growth, improving its morpho-physiological characteristics. The best in planta biostimulant properties were recorded for plants inoculated with strain G33 (Streptomyces xantholiticus MG597585), followed by H14, G10, T45 (Nocardiopsis dassonvillei subsp. dassonvillei MG597502), G22 (Streptomyces xantholiticus MG597582), D14 (Nocardiopsis dassonvillei subsp. dassonvillei MG597514), and J13 (Streptomyces anulatus MG597579). The other strains also showed interesting biostimulant properties. Good correlations were recorded among IAA production, phosphate solubilization, and $\mathrm{HCN}$ release in in vitro results, as well as plant growth and development parameters of samples inoculated with D14, G22, G33, H14, J13, and T45. Further studies should deal with the combination of these strains in consortium, assess their compatibility, and evaluate a possible synergistic effect often described for PGPB consortia. Moreover, their effectiveness should be investigated on different crop plants and under different field conditions. These strains should also be assayed for their salt stress tolerance in vitro (e.g., ACC deaminase activity, PGP traits under salt stress) and in planta (e.g., plant tolerance induction). Salinity of soils is one of current agriculture problems that negatively affects growth and plant development, limiting the productivity of crops. Among the proposals provided to overcome this problem, there is the use of transgenic plants. However, transgenic plant development is expensive and takes a long time for product validation. A practical alternative to reduce negative effects induced by salinity is the use of PGPB. Among them, salt-halotolerant 
strains are physiologically adapted to abiotic changes and can increase the salt tolerance capacity in plants. Thus, given their origin, promising biostimulant properties, and halotolerant traits, our strains could find application in crop cultivation on high-salinity soils. Even so, the present study provides useful information on the utilization of actinomycetal strains as biofertilizers for sustainable agriculture. The growing environmental concern suggests further research and development of these new products, which are relevant to human and planet health. Although there is still more fundamental and applied research to be done, PGPB use rather than use of chemical fertilizers and pesticides-or with a reduced amount of them-can be a successful agricultural practice worldwide that is both efficacious and sustainable.

Author Contributions: Conceptualization, M.K.; methodology, conceptualization M.S.; formal analysis, R.D.; investigation, R.D. and M.P.; resources, M.K. and M.D.G.; data curation, R.D. and M.P.; writing-original draft preparation, R.D. and M.P.; writing — review and editing, M.D.G. All authors have read and agreed to the published version of the manuscript.

Funding: This research was funded by the Ministry of Higher Education and Scientific Research, Algeria.

Acknowledgments: We acknowledge Lorenzo Arrizza for the technical support in the SEM analysis.

Conflicts of Interest: The authors declare no conflict of interest. The funders had no role in the design of the study; in the collection, analyses, or interpretation of data; in the writing of the manuscript, or in the decision to publish the results.

\section{References}

1. Nath, S.; Matozzo, V.; Bhandari, D.; Faggio, C. Growth and liver histology of Channa punctatus exposed to a common biofertilizer. Nat. Prod. Res. 2019, 33, 1591-1598. [CrossRef] [PubMed]

2. Savci, S. An agricultural pollutant: Chemical fertilizer. Int. J. Environ. Sci. Dev. 2012, 3, 73. [CrossRef]

3. Campos, E.V.; Proença, P.L.; Oliveira, J.L.; Bakshi, M.; Abhilash, P.C.; Fraceto, L.F. Use of botanical insecticides for sustainable agriculture: Future perspectives. Ecol. Indic. 2019, 105, 483-495. [CrossRef]

4. Mia, M.B.; Shamsuddin, Z.H.; Mahmood, M. Use of plant growth promoting bacteria in banana: A new insight for sustainable banana production. Int. J. Agric. Biol. 2010, 12, 459-467.

5. Gamez, R.; Cardinale, M.; Montes, M.; Ramirez, S.; Schnell, S.; Rodriguez, F. Screening, plant growth promotion and root colonization pattern of two rhizobacteria (Pseudomonas fluorescens Ps006 and Bacillus amyloliquefaciens Bs006) on banana cv. Williams (Musa acuminata Colla). Microbiol. Res. 2019, 220, 12-20. [CrossRef] [PubMed]

6. Wu, S.C.; Cao, Z.H.; Li, Z.G.; Cheung, K.C.; Wong, M.H. Effects of biofertilizer containing N-fixer, P and K solubilizers and AM fungi on maize growth: A greenhouse trial. Geoderma 2005, 125, 155-166. [CrossRef]

7. Gupta, G.; Parihar, S.S.; Ahirwar, N.K.; Snehi, S.K.; Singh, V. Plant growth promoting rhizobacteria (PGPR): Current and future prospects for development of sustainable agriculture. J. Microb. Biochem. Technol. 2015, 7, 096-102.

8. Shilev, S. Soil rhizobacteria regulating the uptake of nutrients and undesirable elements by plants. In Plant Microbe Symbiosis: Fundamentals and Advances; Springer: New Delhi, India, 2013; pp. 147-167.

9. Bhattacharyya, P.N.; Jha, D.K. Plant growth-promoting rhizobacteria (PGPR): Emergence in agriculture. World J. Microbiol. Biotechnol. 2012, 28, 1327-1350. [CrossRef] [PubMed]

10. Glick, B.R.; Bashan, Y. Genetic manipulation of plant growth-promoting bacteria to enhance biocontrol of phytopathogens. Biotechnol. Adv. 1997, 15, 353-378. [CrossRef]

11. Kyaw, E.P.; Soe, M.M.; San San Yu, Z.K.L.; Lynn, T.M. Study on plant growth promoting activities of Azotobacter isolates for sustainable agriculture in Myanmar. J. Biotech. Biores. 2019, 1, JBB.000524.

12. Ivushkin, K.; Bartholomeus, H.; Bregt, A.K.; Pulatov, A.; Franceschini, M.H.D.; Kramer, H.; van Loo, E.N.; Jaramillo Roman, V.; Finkers, R. UAV based soil salinity assessment of cropland. Geoderma 2019, 338, 502-512. [CrossRef]

13. Zanetti, F.; Zegada-Lizarazu, W.; Lambertini, C.; Monti, A. Salinity effects on germination, seedlings and full-grown plants of upland and lowland switchgrass cultivars. Biomass Bioenergy 2019, 120, $273-280$. [CrossRef] 
14. Egamberdieva, D.; Wirth, S.; Bellingrath-Kimura, S.D.; Mishra, J.; Arora, N.K. Salt-Tolerant Plant Growth Promoting Rhizobacteria for Enhancing Crop Productivity of Saline Soils. Front. Microbiol. 2019, 10, 2791. [CrossRef] [PubMed]

15. Pace, L.; Pellegrini, M.; Palmieri, S.; Rocchi, R.; Lippa, L.; Del Gallo, M. Plant growth-promoting rhizobacteria for In Vitro and Ex Vitro performance enhancement of Apennines' genepì (Artemisia umbelliformis subsp. eriantha), an endangered phytotherapeutic plant. Vitro Cell. Dev. Biol. Plant 2020, 56, 134-142. [CrossRef]

16. Olanrewaju, O.S.; Babalola, O.O. Streptomyces: Implications and interactions in plant growth promotion. Appl. Microbiol. Biotechnol. 2019, 103, 1179-1188. [CrossRef] [PubMed]

17. Toumatia, O.; Yekkour, A.; Goudjal, Y.; Riba, A.; Coppel, Y.; Mathieu, F.; Sabaou, N.; Zitouni, A. Antifungal properties of an actinomycin D-producing strain, Streptomyces sp. IA1, isolated from a Saharan soil. J. Basic Microbiol. 2015, 55, 221-228. [CrossRef] [PubMed]

18. Olanrewaju, O.S.; Glick, B.R.; Babalola, O.O. Mechanisms of action of plant growth promoting bacteria. World J. Microbiol. Biotechnol. 2017, 33, 197. [CrossRef]

19. Goudjal, Y.; Toumatia, O.; Yekkour, A.; Sabaou, N.; Mathieu, F.; Zitouni, A. Biocontrol of Rhizoctonia solani damping-off and promotion of tomato plant growth by endophytic actinomycetes isolated from native plants of Algerian Sahara. Microbiol. Res. 2014, 169, 59-65. [CrossRef] [PubMed]

20. Jog, R.; Nareshkumar, G.; Rajkumar, S. Enhancing soil health and plant growth promotion by actinomycetes. In Plant Growth Promoting Actinobacteria; Springer: Singapore, 2016; pp. 33-45.

21. Wahyudi, A.T.; Priyanto, J.A.; Afrista, R.; Kurniati, D.; Astuti, R.I.; Akhdiya, A. Plant growth promoting activity of actinomycetes isolated from soybean rhizosphere. Online J. Biol. Sci. 2019, 19, 1-8. [CrossRef]

22. Jog, R.; Pandya, M.; Nareshkumar, G.; Rajkumar, S. Mechanism of phosphate solubilization and antifungal activity of Streptomyces spp. isolated from wheat roots and rhizosphere and their application in improving plant growth. Microbiology 2014, 160, 778-788. [CrossRef]

23. Boukaya, N.; Goudjal, Y.; Zamoum, M.; Chaabane Chaouch, F.; Sabaou, N.; Mathieu, F.; Zitouni, A. Biocontrol and plant-growth-promoting capacities of actinobacterial strains from the Algerian Sahara and characterisation of Streptosporangium becharense SG1 as a promising biocontrol agent. Biocontrol Sci. Technol. 2018, 28, 858-873. [CrossRef]

24. Chen, W.; Xie, T.-T.; Zeng, H. Formation, antibiotic resistance, and control strategies of Staphylococcus epidermidis biofilm. In Bacterial Biofilms; IntechOpen: London, UK, 2019.

25. Smati, M.; Kitouni, M. Diversity of actinobacteria in the marshes of Ezzemoul and Djendli in northeastern Algeria. Eur. J. Ecol. 2019, 5, 41-53. [CrossRef]

26. Nautiyal, C.S. An efficient microbiological growth medium for screening phosphate solubilizing microorganisms. FEMS Microbiol. Lett. 1999, 170, 265-270. [CrossRef] [PubMed]

27. Pikovskaya, R.I. Mobilization of phosphorus in soil in connection with the vital activity of some microbial species. Microbiology 1948, 17, 362-370.

28. Hafsa, C.S.; Allaoua, S.; Mostefa, G.; Bilal, Y.; Fouzia, A. Solubilization of phosphate by the Bacillus under salt stress and in the presence of osmoprotectant compounds. Afr. J. Microbiol. Res. 2013, 7, 4562-4571. [CrossRef]

29. Olsen, S.R.; Sommers, L.E.; Page, A.L. Phosphorus. In Methods of Soil Analisis, 2nd ed.; Page, A.L., Miller, R.H., Keeney, D.R., Eds.; American Society of Agronomy: Madison, WI, USA, 1982; pp. 403-430.

30. Gordon, S.A.; Weber, R.P. Colorimetric estimation of indoleacetic acid. Plant Physiol. 1951, 26, 192. [CrossRef]

31. Fatmawati, U.; Meryandini, A.; Nawangsih, A.A.; Wahyudi, A.T. Screening and characterization of actinomycetes isolated from soybean rhizosphere for promoting plant growth. Biodivers. J. Biol. Divers. 2019, 20, 2970-2977. [CrossRef]

32. Donate-Correa, J.; León-Barrios, M.; Pérez-Galdona, R. Screening for plant growth-promoting rhizobacteria in Chamaecytisus proliferus (tagasaste), a forage tree-shrub legume endemic to the Canary Islands. Plant Soil 2005, 266, 261-272. [CrossRef]

33. Cappuccino, J.G.; Sherman, N. Microbiology - A Laboratory Manual; The Benjamin/Cummings Publishing Co., Inc.: Menlo Park, CA, USA, 1992; pp. 188-247.

34. Pranay, K.; Padmadeo, S.R.; Jha, V.; Prasad, B. Screening and identification of amylase producing strains of Bacillus. J. Appl. Biol. Biotech. 2019, 7, 57-62. 
35. Chaiharn, M.; Chunhaleuchanon, S.; Kozo, A.; Lumyong, S. Screening of rhizobacteria for their plant growth promoting activities. Curr. Appl. Sci. Technol. 2008, 8, 18-23.

36. Raval, K.M.; Vaswani, P.S.; Majumder, D.R. Biotransformation of a single amino-acid L-tyrosine into a bioactive molecule L-DOPA. Int. J. Sci. Res. 2012, 2, 2250-3153.

37. Nonomura, H. Key for classification and identification of 458 species of the Streptomycetes included in ISP. J. Ferment. Technol. 1974, 52, 78-92.

38. Prasad, P.; Bedi, S.; Singh, T. In Vitro cellulose rich organic material degradation by cellulolytic Streptomyces albospinus (MTCC 8768). Malays. J. Microbiol. 2012, 8, 164-169. [CrossRef]

39. Dellaras, C. Pratique en Microbiologie de Laboratoire? Recherche de Bactéries et de Levures-Moisissures; Lavoisier: Paris, France, 2014; pp. 65-120.

40. Nitsch, B.; Kutzner, H.J. Egg-yolk agar as a diagnostic medium for Streptomycetes. Experientia 1969, 25, 220-221. [CrossRef]

41. Hankin, L.; Zucker, M.; Sands, D.C. Improved solid medium for the detection and enumeration of pectolytic bacteria. Appl. Environ. Microbiol. 1971, 22, 205-209. [CrossRef]

42. Pagnani, G.; Galieni, A.; Stagnari, F.; Pellegrini, M.; Del Gallo, M.; Pisante, M. Open field inoculation with PGPR as a strategy to manage fertilization of ancient Triticum genotypes. Biol. Fertil. Soils 2020, 56, 111-124. [CrossRef]

43. Pagnani, G.; Pellegrini, M.; Galieni, A.; D’Egidio, S.; Matteucci, F.; Ricci, A.; Stagnari, F.; Sergi, M.; Sterzo, C.L.; Pisante, M. Plant growth-promoting rhizobacteria (PGPR) in Cannabis sativa 'Finola' cultivation: An alternative fertilization strategy to improve plant growth and quality characteristics. Ind. Crops Prod. 2018, 123, 75-83. [CrossRef]

44. Murashige, T.; Skoog, F. A revised medium for rapid growth and bio assays with tobacco tissue cultures. Physiol. Plant. 1962, 15, 473-497. [CrossRef]

45. Silini, A.; Cherif-Silini, H.; Yahiaoui, B. Growing varieties durum wheat (Triticum durum) in response to the effect of osmolytes and inoculation by Azotobacter chroococcum under salt stress. Afr. J. Microbiol. Res. 2016, 10, 387-399.

46. Arnon, D.I. Copper enzymes in isolated chloroplasts. Polyphenoloxidase in Beta vulgaris. Plant Physiol. 1949, 24, 1-15. [CrossRef]

47. Franco-Correa, M.; Quintana, A.; Duque, C.; Suarez, C.; Rodríguez, M.X.; Barea, J.-M. Evaluation of actinomycete strains for key traits related with plant growth promotion and mycorrhiza helping activities. Appl. Soil Ecol. 2010, 45, 209-217. [CrossRef]

48. Kaur, T.; Sharma, D.; Kaur, A.; Manhas, R.K. Antagonistic and plant growth promoting activities of endophytic and soil actinomycetes. Arch. Phytopathol. Plant Prot. 2013, 46, 1756-1768. [CrossRef]

49. Gangwar, M.; Dogra, S.; Gupta, U.P.; Kharwar, R.N. Diversity and biopotential of endophytic actinomycetes from three medicinal plants in India. Afr. J. Microbiol. Res. 2014, 8, 184-191.

50. Sebihi, F.Z.; Benguedouar, A.; Benhizia, Y.; Sanchez, J.; Gallego, E. Evaluation of multi-trait plant growth promoting Pseudomonas fluorescens isolated from Constantine Wheat rhizosphere soil (Algeria) and screening there antifungal activity against two species of Fusarium. Adv. Environ. Biol. 2016, 10, 102-116.

51. Khan, M.S.; Zaidi, A.; Ahmad, E. Mechanism of phosphate solubilization and physiological functions of phosphate-solubilizing microorganisms. In Phosphate Solubilizing Microorganisms; Khan, M.S., Zaidi, A., Musarrat, J., Eds.; Springer: Cham, Switzerland, 2014; pp. 31-62.

52. Faried, A.-S.M. Isolation and Characterization of Phosphate Solubilizing Actinomycetes from Rhizosphere Soil. Ph.D. Thesis, Fac of Agric, Assiut University, Assiut, Egypt, 2019.

53. Ahmad, F.; Ahmad, I.; KHAN, M.S. Indole acetic acid production by the indigenous isolates of Azotobacter and fluorescent Pseudomonas in the presence and absence of tryptophan. Turk. J. Biol. 2005, 29, 29-34.

54. Radwan, T.E.-S.E.-D.; Mohamed, Z.K.; Reis, V. Production of indole-3-acetic acid by different strains of Azospirillum and Herbaspirillum spp. Symbiosis 2002, 32, 39-54.

55. Barazani, O.Z.; Friedman, J. Is IAA the major root growth factor secreted from plant-growth-mediating bacteria? J. Chem. Ecol. 1999, 25, 2397-2406. [CrossRef]

56. Silini, A. Effets des Molécules Osmoprotectrices sur la Survie et L'activité de Azotobacter et sur la Croissance du blé dur en Milieu Salin. Ph.D. Thesis, Université Ferhat Abbas de Sétif, Sétif, Algeria, 2013. 
57. Glick, B.R. The enhancement of plant growth by free-living bacteria. Can. J. Microbiol. 1995, 41, $109-117$. [CrossRef]

58. Dastager, S.G.; Deepa, C.K.; Pandey, A. Potential plant growth-promoting activity of Serratia nematodiphila NII-0928 on black pepper (Piper nigrum L.). World J. Microbiol. Biotechnol. 2011, 27, 259-265. [CrossRef]

59. Patten, C.L.; Glick, B.R. Role of Pseudomonas putida indoleacetic acid in development of the host plant root system. Appl Environ. Microbiol. 2002, 68, 3795-3801. [CrossRef]

60. Mirza, M.S.; Ahmad, W.; Latif, F.; Haurat, J.; Bally, R.; Normand, P.; Malik, K.A. Isolation, partial characterization, and the effect of plant growth-promoting bacteria (PGPB) on micro-propagated sugarcane In Vitro. Plant Soil 2001, 237, 47-54. [CrossRef]

61. Ashwini, M.; Doddamani, L.C.; Babar, S.R. Characterization and evaluation of actinomycete isolates for traits associated with plant growth promotion. J. Pharmacogn. Phytochem. 2018, 7, 1177-1180.

62. Sreevidya, M.; Gopalakrishnan, S.; Kudapa, H.; Varshney, R.K. Exploring plant growth-promotion actinomycetes from vermicompost and rhizosphere soil for yield enhancement in chickpea. Braz. J. Microbiol. 2016, 47, 85-95. [CrossRef] [PubMed]

63. Ahmad, F.; Ahmad, I.; Khan, M.S. Screening of free-living rhizospheric bacteria for their multiple plant growth promoting activities. Microbiol. Res. 2008, 163, 173-181. [CrossRef] [PubMed]

64. Kumar, A.; Kumar, A.; Devi, S.; Patil, S.; Payal, C.; Negi, S. Isolation, screening and characterization of bacteria from Rhizospheric soils for different plant growth promotion (PGP) activities: An In Vitro study. Recent Res. Sci. Technol. 2012, 4, 1-5.

65. Bashan, Y.; De-Bashan, L.E. Bacteria/Plant growth-promotion. In Encyclopedia of Soils in the Environment; Hillel, D., Ed.; Elsevier: Oxford, UK, 2005; Volume 1, pp. 103-115.

66. Joseph, B.; Ranjan Patra, R.; Lawrence, R. Characterization of plant growth promoting rhizobacteria associated with chickpea (Cicer arietinum L.). Int. J. Plant Prod. 2012, 1, 141-152.

67. Mota, M.S.; Gomes, C.B.; Souza Júnior, I.T.; Moura, A.B. Bacterial selection for biological control of plant disease: Criterion determination and validation. Braz. J. Microbiol. 2017, 48, 62-70. [CrossRef]

68. Passari, A.K.; Mishra, V.K.; Gupta, V.K.; Yadav, M.K.; Saikia, R.; Singh, B.P. In Vitro and In Vivo plant growth promoting activities and DNA fingerprinting of antagonistic endophytic actinomycetes associates with medicinal plants. PLoS ONE 2015, 10, e0139468. [CrossRef]

69. Weise, T.; Kai, M.; Piechulla, B. Bacterial ammonia causes significant plant growth inhibition. PLoS ONE 2013, 8, e63538. [CrossRef]

70. Reetha, S.; Selvakumar, G.; Bhuvaneswari, G.; Thamizhiniyan, P.; Ravimycin, T. Screening of cellulase and pectinase by using Pseudomonas fluorescens and Bacillus subtilis. Int. Lett. Nat. Sci. 2014, 13, 75-80.

71. Turan, M.; Nikerel, E.; Kaya, K.; Kitir, N.; Gunes, A.; Mokhtari, N.E.P.; Tüfenkçi, Ş.; Karaman, M.R.; Çimrin, K.M. Enzyme Dynamic in Plant Nutrition Uptake and Plant Nutrition. In Enzyme Inhibitors and Activators; Senturk, M., Ed.; Inctechopen: London, UK, 2017; pp. 225-242.

72. Mushtaq, S.; Shafiq, M.; Ashraf, T.; Haider, M.S.; Ashfaq, M.; Ali, M. Characterization of plant growth promoting activities of bacterial endophytes and their antibacterial potential isolated from citrus. J. Anim. Plant Sci. 2019, 29, 978-991.

73. Vranova, V.; Rejsek, K.; Formanek, P. Proteolytic activity in soil: A review. Appl. Soil Ecol. 2013, 70, $23-32$. [CrossRef]

74. Stach, N.; Kaszycki, P.; W \ladyka, B.; Dubin, G. Extracellular proteases of Staphylococcus spp. In Pet-to-Man Travelling Staphylococci; Savini, V., Ed.; Academic Press: Cambridge, MA, USA, 2018; pp. 135-145.

75. Vardharajula, S.; SkZ, A.; Shiva Krishna Prasad Vurukonda, S.; Shrivastava, M. Plant growth promoting endophytes and their interaction with plants to alleviate abiotic stress. Curr. Biotechnol. 2017, 6, 252-263. [CrossRef]

76. Islam, R.; Datta, B. Diversity of chitinases and their industrial potential. Int. J. Appl. Res. 2015, 1, 55-60.

77. Pascoal, A.; Estevinho, L.M.; Martins, I.M.; Choupina, A.B. Novel sources and functions of microbial lipases and their role in the infection mechanisms. Physiol. Mol. Plant Pathol. 2018, 104, 119-126. [CrossRef]

78. Dal Cortivo, C.; Barion, G.; Visioli, G.; Mattarozzi, M.; Mosca, G.; Vamerali, T. Increased root growth and nitrogen accumulation in common wheat following PGPR inoculation: Assessment of plant-microbe interactions by ESEM. Agric. Ecosyst. Environ. 2017, 247, 396-408. [CrossRef] 
79. Primo, E.D.; Ruiz, F.; Masciarelli, O.; Giordano, W. Biofilm formation and biosurfactant activity in plant-associated bacteria. In Bacterial Metabolites in Sustainable Agroecosystem; Maheshwari, D., Ed.; Springer: Cham, Switzerland, 2015; Volume 12, pp. 337-349.

80. Patel, K.B.; Thakker, J.N. Growth promotion and biocontrol activity of Nocardiopsis dassonvillei strain YM12: An isolate from coastal agricultural land of Khambhat. Vegetos 2019, 32, 571-582. [CrossRef]

(C) 2020 by the authors. Licensee MDPI, Basel, Switzerland. This article is an open access article distributed under the terms and conditions of the Creative Commons Attribution (CC BY) license (http://creativecommons.org/licenses/by/4.0/). 